\title{
DC SIGNR silencing reduces HIV-1 infection in Dendritic cells
}

\author{
Omkar Chaudhary ${ }^{1}$, Sanjeev Kumar ${ }^{1}$, Heena Aggarwal ${ }^{1}$, Muzamil A Makhdoomi', Jasbir Singh ${ }^{2,3}$, Anjali Hazarika ${ }^{3}$, \\ Kalpana Luthra ${ }^{1^{*}}$
}

From 2nd International Science Symposium on HIV and Infectious Diseases (HIV SCIENCE 2014)

Chennai, India. 30 January - 1 February 2014

\section{Background}

Dendritic cells (DCs) capture HIV-1 from periphery via DC SIGN/R receptors and transfer to T cells. It has been reported that siRNA directed against DC SIGN significantly inhibits HIV infection of DCs. In this study, the expression of DC SIGN/R and its role in HIV-1 infectivity of DCs were assessed.

\section{Methods}

DCs were cultured from monocytes from healthy donors and infected with HIV-1 Indian clade C virus. DC SIGN/ $\mathrm{R}$ expression on DCs was determined by RealTime PCR. The effect of down regulation of this receptor in DCs using DC SIGN/R siRNA on the infection with HIV-1 was assessed. Statistical significance was calculated by Student's t test.

\section{Results}

High expression of DC SIGN/R was observed on DCs infected with HIV-1 $(p=0.01)$. DC sIGNR expression in DCs was maximally downregulated by siRNA at $24 \mathrm{hrs}$ $(p=0.002)$ and was associated with significant reduction in expression of CD40 ( $p=0.003), \mathrm{CD} 80(p=0.008), \mathrm{CD} 86$ $(p=0.007)$ and P38 MAPK $(p=0.005)$. Transfection of DC SIGNR on DCs at 24 hours followed by infection with clade C HIV-1 demonstrated lower levels of p24 compared to that in untransfected DCs $(p=0.0008)$.

\section{Conclusion}

Data demonstrates that down regulation of DC SIGNR expression on DCs decreases activation that in turn may inhibit DC $\mathrm{T}$ cell interactions needed for progression of

\footnotetext{
* Correspondence: kalpanaluthra@gmail.com

'Dept. of Biochemistry, All India Institute of Medical Sciences, New Delhi, India

Full list of author information is available at the end of the article
}

HIV-1 infection. Reduced p24 antigen production may be mediated by P38 MAPK inhibition. Our finding suggests that blocking DC SIGNR expression on DCs may prevent initial binding of HIV-1 and serve as a first step in prevention of HIV-1 infection.

\begin{abstract}
Authors' details
'Dept. of Biochemistry, All India Institute of Medical Sciences, New Delhi, India. ${ }^{2}$ Dept. of Biochemistry, Kurukshetra University, Kurukshetra, India. ${ }^{3}$ Blood Transfusion Services, Cardiothoracic and Neurosciences Center, All India Institute of Medical Sciences, New Delhi, India.
\end{abstract}

Published: 27 May 2014

doi:10.1186/1471-2334-14-S3-08

Cite this article as: Chaudhary et al.: DC SIGNR silencing reduces HIV-1 infection in Dendritic cells. BMC Infectious Diseases 2014 14(Suppl 3):O8.

\footnotetext{
Submit your next manuscript to BioMed Central and take full advantage of:

- Convenient online submission

- Thorough peer review

- No space constraints or color figure charges

- Immediate publication on acceptance

- Inclusion in PubMed, CAS, Scopus and Google Scholar

- Research which is freely available for redistribution

Submit your manuscript at www.biomedcentral.com/submit
}

C Biomed Central

(c) 2014 Chaudhary et al; licensee BioMed Central Ltd. This is an Open Access article distributed under the terms of the Creative Commons Attribution License (http://creativecommons.org/licenses/by/4.0), which permits unrestricted use, distribution, and reproduction in any medium, provided the original work is properly cited. The Creative Commons Public Domain Dedication waiver (http://creativecommons.org/publicdomain/zero/1.0/) applies to the data made available in this article, unless otherwise stated. 